Participative Journal

Jurnal Pengabdian Pada Masyarakat

Vol. 01, No. 01, April 2021

Homepage journal: https://jurnal.jurmat.com/index.php/pj

\title{
KETERLIBATAN MAHASISWA KKP-DR UIN MATARAM PADA MASA PANDEMI COVID-19 DALAM PROGRAM PENDIDIKAN DAN KESEHATAN DI DESA DASAN TAPEN, GERUNG, LOMBOK BARAT
}

\author{
Muammar $^{* 1}$ \\ *Affiliasi: Universitas Islam Negeri Mataram
}

\begin{abstract}
Corona Virus Disease 19 or known as Covid-19 has changed the order of human life in the world. Life that used to feel good has turned into a big disaster. All aspects of life starting from the economic, social, educational and health aspects have turned into a prolonged and abnormal crisis. The abnormality is not to be lamented but must be able to survive and find a solution. This means that everyone must be involved and take part in efforts to minimize the impact caused by Covid- 19 . One of the government agencies involved for the above purposes is UIN Mataram. The involvement of UIN Mataram here is to direct students to carry out Participatory Work Lectures from Home (KKP $D R$ ). The implementation of the KKP-DR is focused on the education and health aspects. Both aspects are expected that students can be involved to help the government overcome various problems in education and health. In Dasan Tapen Village, Gerung, West Lombok, various efforts were made by students in both aspects. In the field of education, students provide study guidance to school children from elementary to high school levels, while in the health sector, students conduct socialization to prevent the spread of Covid-19.
\end{abstract}

Keywords: student involvement, Covid-19, education, health

Journal Info:

Received, 10 Februari 2021 | Revised, 13 Maret 2021 | Published, 12 April 2021

${ }^{1}$ Corresponden to the author: Prodi PGMI-Fakultas Tarbiyah dan Keguruan- UIN Mataram.

Jl. Gajah Mada Jempong, Indonesia (83116), email address : : muammar@uinmataram.ac.id 


\begin{abstract}
Abstrak
Corona Virus Disease 19 atau dikenal dengan Covid-19 telah mengubah tatanan kehidupan umat manusia di dunia. Kehidupan yang tadinya terasa nyaman telah berubah menjadi musibah besar. Semua aspek kehidupan mulai dari aspek ekonomi, sosial, pendidikan, dan kesehatan telah berubah menjadi krisis yang berkepanjangan dan tidak normal. Ketidaknormalan tersebut bukan untuk diratapi melainkan harus bisa bertahan dan mencari solusinya. Artinya, semua orang harus terlibat dan mengambil bagian dalam usaha meminimalisasi dampak yang ditimbulkan oleh Covid-19 ini. Salah satu lembaga pemerintah yang terlibat untuk maksud di atas adalah UIN Mataram. Keterlibatan UIN Mataram di sini adalah mengarahkan mahasiswanya untuk melaksanakan Kuliah Kerja Partisipatif Dari Rumah (KKP-DR). Pelaksanaan KKP-DR difokuskan pada aspek pendidikan dan kesehatan. Kedua aspek tersebut diharapkan mahasiswa dapat terlibat untuk membantu pemerintah mengatasi berbagai persoalan dalam pendidikan dan kesehatan. Di Desa Dasan Tapen, Gerung, Lombok Barat berbagai upaya dilakukan oleh mahasiswa pada kedua aspek tersebut. Dalam bidang pendidikan, mahasiswa memberikan bimbingan belajar kepada anak sekolah mulai dari jenjang sekolah dasar hingga sekolah menengah, sedangkan pada bidang kesehatan, mahasiswa melakukan sosialisasi pencegahan penyebaran Covid-19.
\end{abstract}

Kata Kunci: keterlibatan mahasiswa, Covid-19, pendidikan, kesehatan

\title{
Pendahuluan
}

Pada tahun 2020, Kuliah Kerja Partisipatif (KKP) dilaksanakan dari rumah atau yang dikenal dengan nama KKP-DR. KKP merupakan salah satu mata kuliah yang wajib diikuti oleh seluruh mahasiswa UIN Mataram melalui bimbingan Dosen Pembimbing Lapangan (DPL) serta berlokasi di beberapa wilayah yang menjadi sasaran pelaksanaan KKP. ${ }^{1}$ KKP bertujuan untuk membekali mahasiswa dalam mengaplikasikan keilmuan yang telah dipelajari selama perkuliahan. Secara khusus, KKP ini bertujuan untuk melibatkan mahasiswa atau partisipasi mahasiswa dalam kegiatan memecahkan berbagai fenomena yang terjadi pada masyarakat melalui pengembangan potensi yang ada pada masyarakat itu sendiri.

Pada awal tahun 2020, Indonesia mengalami pandemik global yaitu munculnya Corona Virus Disease 19 atau dikenal dengan Covid-19. Virus yang diketahui bermula dari China ini telah mengubah tatanan kehidupan masyarakat Indonesia bahkan umat manusia di dunia. Kehidupan yang tadinya terasa nyaman telah berubah menjadi musibah besar. Semua aspek kehidupan mulai dari aspek ekonomi, sosial, pendidikan, dan kesehatan telah berubah menjadi krisis yang berkepanjangan dan tidak normal. Ketidaknormalan tersebut bukan untuk diratapi melainkan harus bisa bertahan dan mencari solusinya. Artinya, semua orang harus terlibat dan mengambil bagian dalam usaha meminimalisasi dampak yang ditimbulkan oleh Covid-19 ini. 
Berbagai kebijakan telah dilakukan oleh pemerintah dalam menanggulangi pandemik tersebut. Salah satunya adalah dengan keterlibatan dan keikutsertaan universitas, dalam hal ini adalah Universitas Islam Negeri (UIN) Mataram. Melalui kebijakan akademis, UIN Mataram dituntut dapat berperan aktif dalam membantu masyarakat dan pemerintah dan dapat menjadi solution maker terhadap permasalahan yang sedang dihadapi.

KKP merupakan salah satu strategi yang dilakukan oleh UIN Mataram. Melalui KKP ini, UIN Mataram berupaya mensinergikan programnya dengan program pemerintah dalam membantu percepatan penanganan dan pencegahan Covid-19. UIN Mataram mengerahkan keterlibatan mahasiswa yang langsung dapat bersentuhan dengan masyarakat melalui program KKP ini. Meskipun pelaksanaan KKP terdampak Covid-19, UIN Mataram tidak menyurutkan keikutsertaannya dalam menangani pandemik yang dihadapi. Berbagai program, strategi, dan kebijakan pun telah diambil untuk menyiasati keterlibatannya, yakni melalui program Kuliah Kerja Partisipatif Dari Rumah (KKP-DR).

Di Desa Dasan Tapen Kecamatan Gerung Kabupaten Lombok Barat, pelaksanaan KKP-DR dilakukan melalui berbagai program pilihan yang sesuai dengan keadan dan kebutuhan di lokasi KKP dengan pemanfaatan IPTEK secara online. Program-program pilihan yang dimaksudkan di sini adalah program pada bidang pendidikan dan bidang kesehatan. Pada bidang pendidikan, mahasiswa membantu masyarakat dalam memberikan bimbingan belajar kepada anak-anak mulai dari jenjang sekolah dasar hingga sekolah menengah. Hal tersebut sesuai dengan kebijakan pemerintah yang mengharapkan anak-anak sekolah untuk belajar dari rumah. Aktivitas belajar dari rumah juga dikondisikan sesuai dengan minat dan kondisi masing-masing anak, termasuk juga mempertimbangkan kesenjangan akses/fasilitas belajar di rumah. ${ }^{2}$ Bahkan, pembelajaran juga dilaksanakan jarak jauh secara daring. ${ }^{3,4}$

Kemudian, pada bidang kesehatan, mahasiswa melakukan sosialisasi pencegahan penyebaran Covid-19. Covid-19 merupakan penyakit jenis baru yang belum pernah diidentifikasi sebelumnya pada manusia. ${ }^{5}$ Virus penyebab Covid-19 ini dinamakan Sars- CoV-2. Virus Corona adalah zoonosis (ditularkan antara hewan dan manusia) ${ }^{6,7}$. Penelitian menyebutkan bahwa SARS ditransmisikan dari kucing luwak (civet cats) ke manusia dan MERS dari unta ke manusia. Adapun, hewan yang menjadi sumber penularan Covid-19 ini masih belum diketahui.

WHO melaporkan bahwa penularan dari manusia ke manusia terbatas (pada kontak erat dan petugas kesehatan) telah dikonfirmasi di China maupun negara lain. Berdasarkan kejadian MERS dan SARS sebelumnya, penularan manusia ke manusia terjadi melalui droplet, kontak dan benda yang terkontaminasi, maka penularan Covid-19 diperkirakan sama. Rekomendasi standar untuk mencegah penyebaran infeksi adalah melalui cuci tangan secara teratur, menerapkan etika batuk dan bersin, menghindari kontak secara langsung dengan ternak dan hewan liar serta menghindari kontak dekat dengan siapa pun yang menunjukkan gejala penyakit pernapasan seperti batuk dan 
bersin. Selain itu, menerapkan Pencegahan dan Pengendalian Infeksi (PPI) saat berada di fasilitas kesehatan terutama unit gawat darurat. ${ }^{8}$

Sampai dengan tanggal 13 Agustus 2020, dilaporkan kasus aktif sebanyak 39.290 atau 29,5\%. Penambahan kasus positif baru sebanyak 2.098 kasus, pasien sembuh 87.558 kasus atau $65,9 \%$, dan meninggal bertambah 5.968 atau 4,49\%. Selain itu, yang tak kalah penting ialah ada 64 kabupaten/kota dari 22 provinsi yang masuk kategori zona oranye selama 4 minggu tanpa perubahan. Rinciannya di Bali, Banten, Bengkulu, DIY, DKI Jakarta, Kalimantan Timur, Jawa Barat, Jawa Tengah, Kalimantan Selatan, Kalimantan Tengah, Maluku Utara, Papua Barat, Riau, Jawa Timur, Sulawesi Utara, Papua, Nusa Tenggara Barat, Sulawesi Barat, Sumatera Barat, Sumatera Selatan, Sulawesi Selatan, dan Sumatera Utara. ${ }^{9}$

Dari data di atas, mahasiswa akan melakukan edukasi kepada masyarakat masyarakat sebagai relawan pencegahan Covid-19. Secara langsung, mahasiswa sebagai bagian dari lingkungan masyarakat itu sendiri dan bekerja sama dengan puskesmas serta posko penanganan terdekat dengan tempat tinggalnya untuk melakukan kampanye kesehatan dan pencegahan Covid 19 melalui platform media sosial seperti instagram, facebook, twitter, whatsapp, youtube serta platform-platfor popular lainnya dalam bentuk video, foto, poster, serta karya tulis dalam bentuk buku.

\section{Metode}

Keterlibatan Mahasiswa KKP-DR UIN Mataram pada Masa Pandemi Covid-19 dalam Program Pendidikan dan Kesehatan di Desa Dasan Tapen Gerung Lombok Barat ini dilaksanakan dengan cara: (1) melakukan sosialisasi program-program KKP-DR UIN Mataram pada pihak desa, (2) melakukan pemetaan program berdasarkan informasi dari desa, (3) menyiapkan sumber daya manusia dan materi, dan (4) melaksanakan bimbingan terhadap anak usia sekolah dari jenjang sekolah dasar hingga menengah dan edukasi masyarakat terkait pencegahan penyebaran Covid19. Sosialisasi program dilakukan setelah mahasiswa diterima oleh pihak desa untuk melakukan KKP-DR. Dari informasi yang diperoleh di desa, mahasiswa melakukan pemetaan program yang akan dilaksanakan. Pemetaan ini dilakukan agar program yang dilaksanakan terukur dan sesuai harapan. Selanjutnya, mahasiswa menyiapkan diri dengan berbagai hal terkait program yang akan dilaksanakan. Terakhir, mahasiswa melaksanakan program berupa bimbingan anak-anak dalam belajar dan edukasi masyarakat mengenai pencegahan penyebaran Covid-19.

\section{Hasil dan Pembahasan}

Keterlibatan mahasiswa KKP-DR UIN Mataram pada Masa Pandemi Covid-19 membawa nuansa baru di Desa Dasan Tapen. Nuansa yang dimaksudkan adalah kembalinya aktivitas 
masyarakat yang digerakkan oleh kehadiran mahasiswa. Mahasiswa bersama perangkat desa mulai dari kepala desa, staf, kepala dusun, tokoh agama, dan tokoh pemuda berdiskusi dan mencari solusi dari berbagai rintangan yang dihadapi pada masa pandemi.

Sebelumnya, aktivitas masyarakat lumpuh total. Tidak ada yang bisa dilakukan kecuali beraktivitas di rumah saja. Semua akses keluar rumah dihentikan. Bahkan, pemerintah memberlakukan social distancing atau menjaga jarak dengan siapa pun. Semua itu sesuai dengan arahan pemerintah untuk bekerja dari rumah, belajar dari rumah, dan beribadah di rumah.

Pembatasan kontak dengan sesama tersebut menjadikan situasi kehidupan masyarakat menjadi tidak normal. Ketidaknormalan sangat terasa karena bekerja tidak boleh, belajar di sekolah tidak boleh, beribadah di masjid tidak boleh, dan seterusnya. Hal itulah yang dipahami dan dipelajari oleh para mahasiswa untuk mencarikan solusinya.

Mahasiswa bersama dengan kelompok masing-masing memiliki pemikiran yang sama tentang kehidupan yang tidak normal tersebut. Bukan berarti kondisi seperti itu dibiarkan, apalagi sampai diabaikan. Dengan diskusi yang dilakukan bersama-sama, tercetus ide untuk berbuat dan mencoba menjadikan situasi kehidupan menjadi normal, tetapi tidak seperti normal sebelumnya, melainkan normal baru atau new normal. Kondisi new norma/ inilah yang menjadi salah satu jalan untuk menapaki jalan-jalan berikutnya untuk keluar dari ketidaknormalan yang dimaksudkan di atas.

Berdasarkan observasi dan informasi dari berbagai sumber, mahasiswa KKP-DR di Desa Dasan Tapen berinisiatif mensosialisasikannya kepada masyarakat melalui pihak desa, yakni kepala desa dan jajarannya. Inisiatif tersebut terkait dengan program kerja yang akan dilakukan dan yang telah dipilih serta sejalan dengan permasalahan yang dihadapi. Kepada pihak desa, mahasiswa menawarkan program pendidikan dan program kesehatan. Kedua program inilah yang akan dimaksimalkan sehingga memberikan dampak dan manfaat bagi masyarakat. Berikut diuraikan satu per satu.

\section{Program Pendidikan}

Pada masa pandemi Covid-19, pendidikan harus terus berjalan. Dengan pendidikan, kualitas anak bangsa akan meningkat. Artinya, upaya peningkatan mutu pendidikan menjadi prioritas utama.

Melalui Kementerian Pendidikan dan Kebudyaan, pemerintah menginstruksikan agar pendidikan terus berjalan dengan dilakukan berbagai upaya penyesuaian pembelajaran. Pemerintah menyarankan masyarakat agar belajar dari rumah. Hal tersebut merupakan wujud dari pemenuhan hak anak untuk mendapatkan layanan pendidikan selama darurat penyebaran Corona Virus Disease (Covid- 19). Belajar dari Rumah selama darurat penyebaran Corona Virus Disease 
(Covid- 19) dilaksanakan dengan tetap memperhatikan protokol penanganan Covid-19 dan juga melalui pembelajaran jarak jauh daring dan/atau luring dilaksanakan sesuai dengan pedoman yang telah dibuat.

Atas dasar tersebut, mahasiswa KKP-DR mengambil bagian sebagai pendamping anak-anak belajar dari rumah (BDR). Mahasiswa melakukan upaya-upaya pendekatan dengan tetap memperhatikan protokol kesehatan yang disarankan. Artinya, keselamatan dan kesehatan lahir batin anak dan mahasiswa menjadi pertimbangan utama dalam pelaksanaan pendampingan belajar dari rumah (BDR). Pendampingan dilakukan untuk memberikan pengalaman belajar yang bermakna bagi anak-anak, tanpa terbebani tuntutan menuntaskan seluruh capaian kurikulum seperti di sekolah. BDR pun difokuskan pada pendidikan kecakapan hidup, antara lain mengenai pandemi Covid-19. Materi pembelajaran juga bersifat inklusif sesuai dengan usia dan jenjang pendidikan, konteks budaya, karakter dan jenis kekhususan anak-anak. Aktivitas dan penugasan selama BDR divariasikan sesuai minat dan kondisi masing-masing, termasuk mempertimbangkan kesenjangan akses terhadap fasilitas BDR. Hal utama dari semua di atas adalah mengedepankan pola interaksi dan komunikasi yang positif antara mahasiswa dengan orang tua/wali. ${ }^{10}$

Setelah sosialisasi kepada pihak desa, mahasiswa KKP-DR diminta untuk membantu masyarakat dalam memberikan dampingan belajar kepada anak-anak. Dampingan belajar yang dilakukan adalah kunjungan belajar ke rumah-rumah, membentuk kelompok belajar, kelompok mengaji al-Qur'an, dan sebagainya. Pendampingan yang akan diberikan disesuaikan dengan bidang dan kemampuan mahasiswa.

Dari arahan kepala desa di atas, para mahasiswa melakukan persiapan-persiapan. Persiapan yang dilakukan adalah berbagi tugas dengan anggota kelompok. Namun, setelah didiskusikan, dikarenakan jumlah mahasiswa yang tidak banyak, akhirnya pelaksanaan dampingan belajar tersebut dilakukan secara bersama-sama. Berikut ini dapat dilihat dampingan belajar yang dilaksanakan mahasiswa KKP-DR di Desa Dasan Tapen.

\section{a. Mahasiswa berkunjung ke rumah warga untuk memberikan dampingan belajar}

Mahasiswa KKP-DR melakukan kunjungan ke rumah warga untuk mendampingi anak-anak dalam belajar. Anak-anak didampingi berdasarkan pelajaran yang diberikan oleh gurunya. Anak-anak terlebih dahulu menjelaskan pelajaran atau tugas yang diberikan oleh gurunya. Dengan cermat, mahasiswa memahami yang dijelaskan oleh anak-anak dan membantu mereka berdasakan kesulitannya. Gambar 1 di bawah ini terlihat anak-anak serius mengikuti bimbingan belajar yang diberikan oleh mahasiswa KKP-DR UIN Mataram.

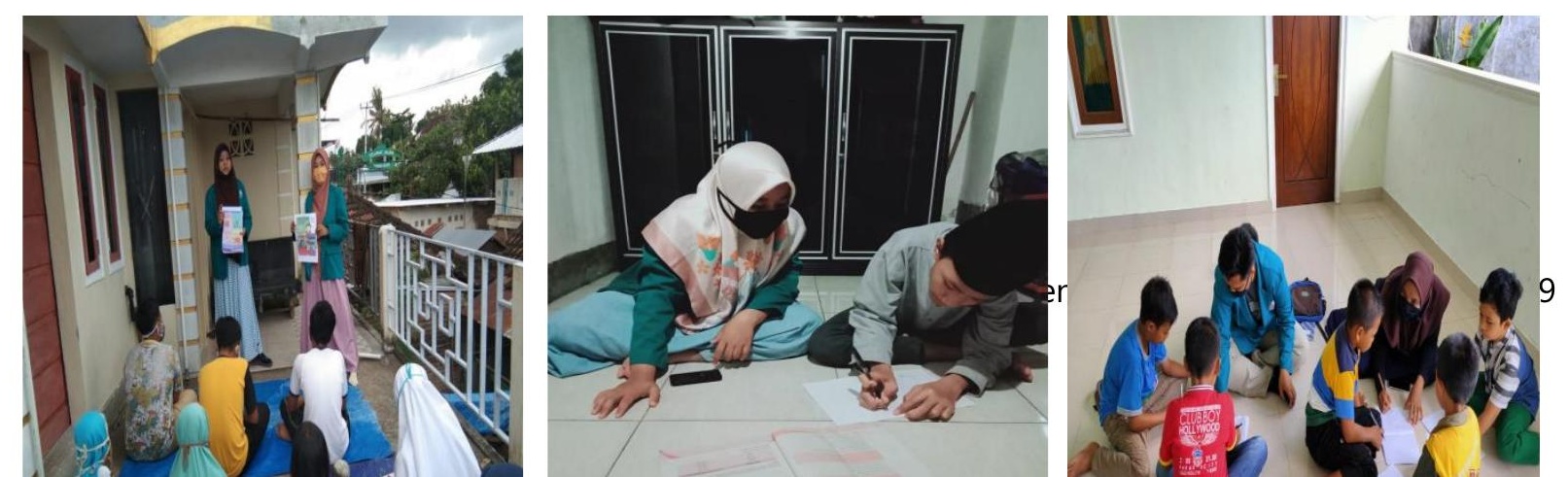




\section{Gambar 1}

Mahasiswa KKP-DR Mendampingi Anak-Anak Belajar

\section{b. Mahasiswa membentuk kelompok belajar}

Mahasiswa KKP-DR juga membentuk kelompok belajar. Kelompok belajar yang dibentuk berdasarkan masukan dari anak-anak. Artinya, kelompok belajar yang dibentuk ini atas kemamuan anak-anak. Hal tersebut juga menjadi lebih mudah bagi mahasiswa dalam pelaksanaannya karena diinisiasi oleh anak-anak itu sendiri. Gambar 2 di bawah ini terlihat anak-anak asyik belajar bahasa Inggris dan bahasa Arab dengan kelompok masing-masing.
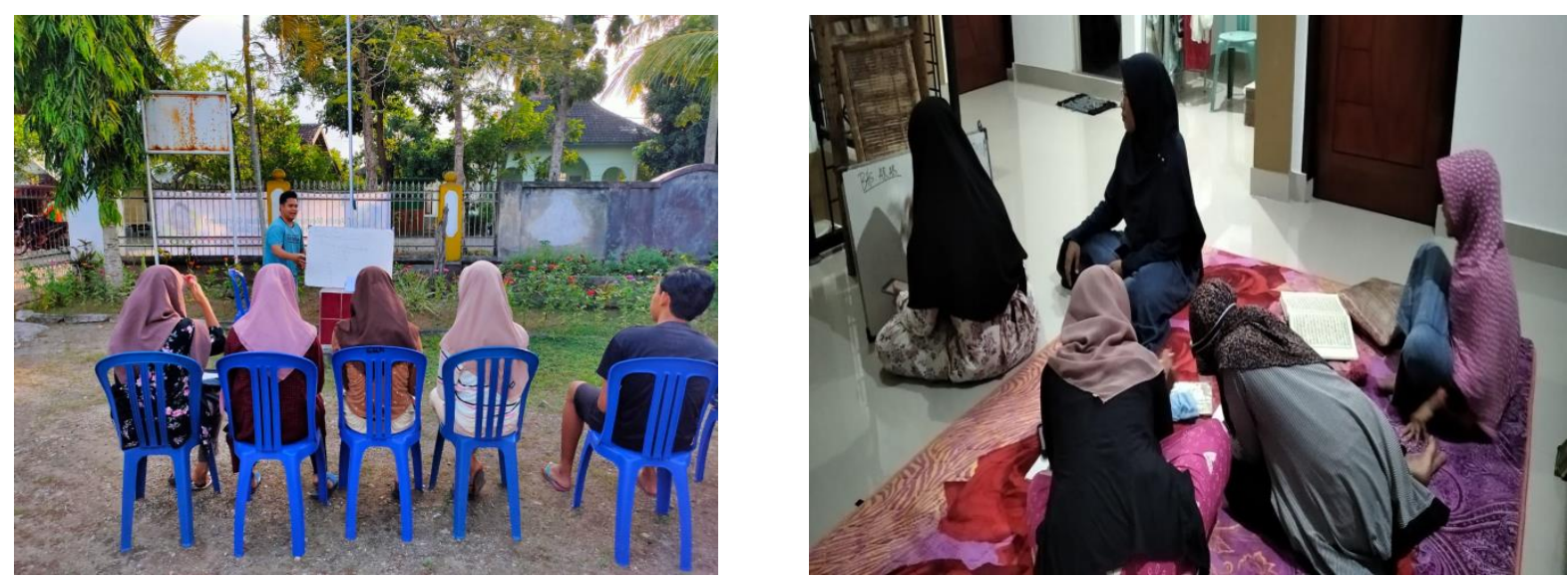

\section{Gambar 2}

Mahasiswa KKP-DR Mendampingi Kelompok Belajar Bahasa Inggris dan Bahasa Arab

\section{c. Mahasiswa mendampingi kelompok mengaji al-Qur'an}

Mahasiswa KKP-DR juga mendampingi kelompok mengaji al-Qur'an. Kelompok mengaji didampingi pada malam dan sore hari. Pendampingan dilaksanakan di masjid dan ada juga di rumah warga. Selama pandemi Covid-19, kegiatan dibatasi selama 1 jam. Hal tersebut diminta 
oleh satuan tugas Covid-19 di kampung masing-masing. Gambar 3 di bawah ini terlihat anakanak didampingi mengaji al-Qur'an.
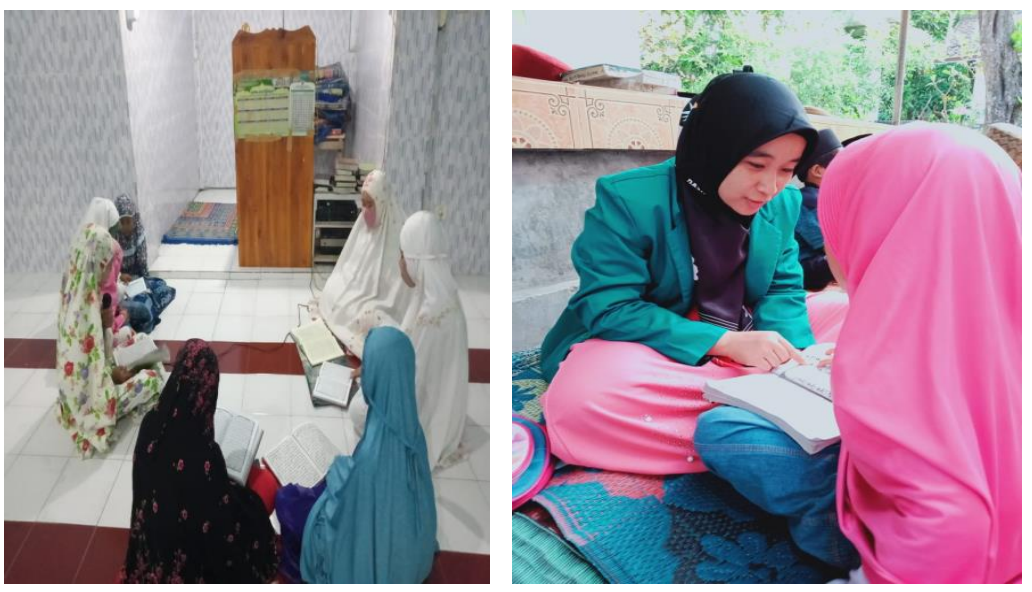

Gambar 3

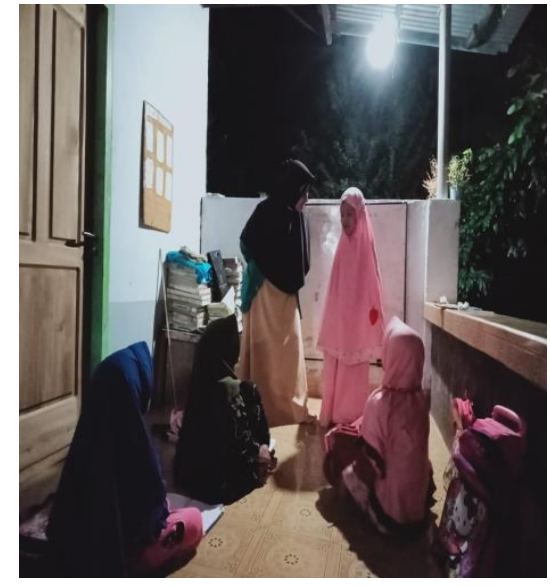

Mahasiswa KKP-DR Mendampingi Kelompok Mengaji Al-Qur'an

\section{Program Kesehatan}

Kesehatan merupakan nikmat terbesar yang Allah berikan kepada umat manusia di dunia. Karena sehat, manusia dapat menjalankan aktivitasnya di muka bumi untuk beribadah dan aktivitas keduniaan lainnya. Manusia harus mensyukuri itu meskipun saat ini dilanda oleh musibah besar, yaitu Covid-19.

Covid-19 menjadi realitas penyakit yang mengubah struktur sosial masyarakat. Perilaku sosial berubah, begitu pun kohesi sosial. Cara (usage), kebiasaan (folkways), tata kelakuan (mores), dan adat istiadat (custom) turut beradaptasi. Secara sosiologis setidaknya pandemi Covid-19 terkonstruksi empat persepsi di masyarakat.

Pertama, Covid-19 merupakan jenis penyakit yang berbahaya. Sejak ditemukan Covid-19 di Wuhan China, Covid-19 diyakini oleh para ahli kesehatan tidak begitu tinggi tingkat persentase kematiannya daripada virus lain seperti SARS dan MERS. ${ }^{11}$ Namun, Covid-19 menjadi virus berbahaya karena tingkat penyebarannya sangat cepat dibandingkan dengan virus lain. Itu terbukti dengan cepatnya penduduk di dunia yang terinfeksi Covid-19.

Kedua, Covid-19 merupakan ancaman bagi berbagai sektor kehidupan. Selain kesehatan, Covid-19 turut mengancam kehidupan sosial, ekonomi, pendidikan, dan politik di berbagai negara. Pada aspek kehidupan sosial, hubungan sosial terbatasi, disorganisasi, dan disfungsi sosial terjadi di masyarakat. Sementara pada aspek ekonomi, tingkat kemiskinan meningkat dan mekanisme transaksi perdagangan berbasis online. ${ }^{12,13}$ Pada sektor pendidikan, model 
pembelajaran harus dilakukan jarak jauh secara daring ${ }^{14,15}$ Pada kehidupan politik juga tidak lepas terkena dampaknya. Ego sektoral antarlembaga pemerintah dan politik dramaturgi untuk meraih simpati masyarakat menjadi fenomena dalam konteks politik di tengah pandemi Covid19.

Ketiga, Covid-19 diyakini oleh beberapa pihak sebagai bentuk konspirasi global yang sengaja dibuat untuk kepentingan kapitalisme dan penjajahan model baru berbasis senjata biologis. Walaupun belum ada studi ilmiah terkait dengan persepsi ini, hal ini menjadi menarik karena banyaknya perdebatan yang terjadi di masyarakat. Saat masyarakat mulai mengalami berbagai tekanan mekanisme hidup di tengah pandemi Covid-19, rasa ketidakpercayaan masyarakat muncul dan dapat meyakini persepsi ini. Teori konspirasi global berkembang dan menjadi hipotesis masyarakat dalam situasi yang tidak menentu.

Keempat, pandemi Covid-19 sebagai sumber pendapatan ekonomi baru. Pada persepsi ini beberapa pihak meyakini bahwa pandemi Covid-19 menguntungkan bagi dirinya, bagi kelompoknya, dan bagi perusahaannya untuk meningkatkan sumber pendapatan ekonomi. Persepsi keempat inilah yang melahirkan para aktor ekonomi yang menaikkan harga barang jauh lebih tinggi daripada harga sebenarnya karena permintaan masyarakat yang tinggi. Aktor ekonomi ini tidak peduli dengan rasa simpati dan empati di masa pandemi, bagi mereka bisnis adalah bisnis.

Atas dasar tersebut, mahasiswa KKP-DR UIN Mataram melakukan edukasi kepada masyarakat terkait Covid-19. Edukasi yang dilakukan berupa kerja nyata pencegahan dan penyebaran Covid-19, seperti: penyebaran pamflet, sosialisasi hidup bersih dan sehat, pembagian masker, pembuatan dan pembagian hand sanitizer, serta penyemprotan disinfektan. Untuk lebih jelasnya, diuraikan sebagai berikut.

\section{a. Penyebaran pamflet}

Mahasiswa KKP-DR UIN Mataram melakukan penyebaran pamflet. Penyebaran pamflet dimaksudkan untuk mengedukasi masyarakat terkait Covid-19. Dengan bekerjasama dengan pihak desa, mahasiswa menyebarkan pamflet di beberapa titik yang dianggap efektif. Gambar 4 di bawah berikut terlihat mahasiswa menyebarkan pamflet di beberapa tempat di Desa Dasan Tapen.
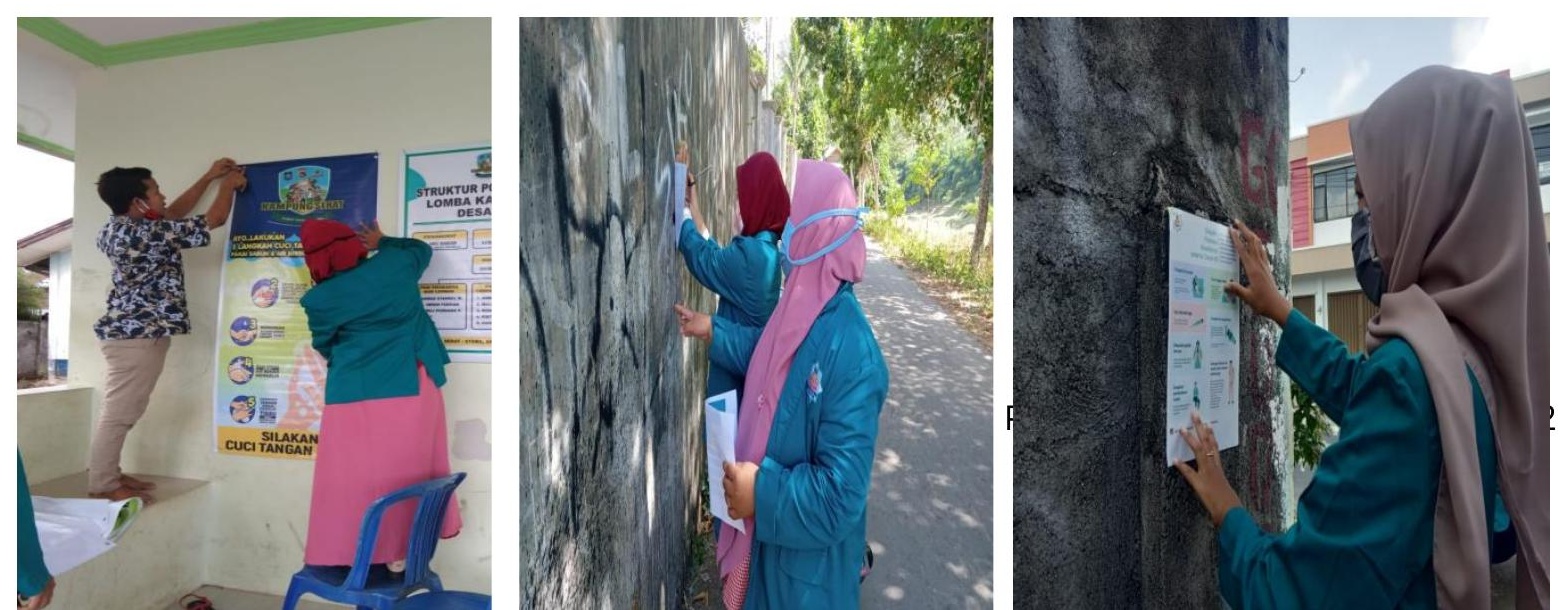


\section{Gambar 4}

Penyebaran Pamflet

\section{b. Sosialisasi Hidup Bersih dan Sehat}

Mahasiswa KKP-DR UIN Mataram mensosialisasikan tata cara hidup bersih dan sehat. Masyarakat dibimbing cara mencuci tangan, menjaga lingkungan, dan menerapkan pola hidup bersih dan sehat dalam kehidupan sehari-hari. Gambar 5 di bawah berikut terlihat mahasiswa KKP-DR UIN Mataram membimbing warga hidup bersih dan sehat.
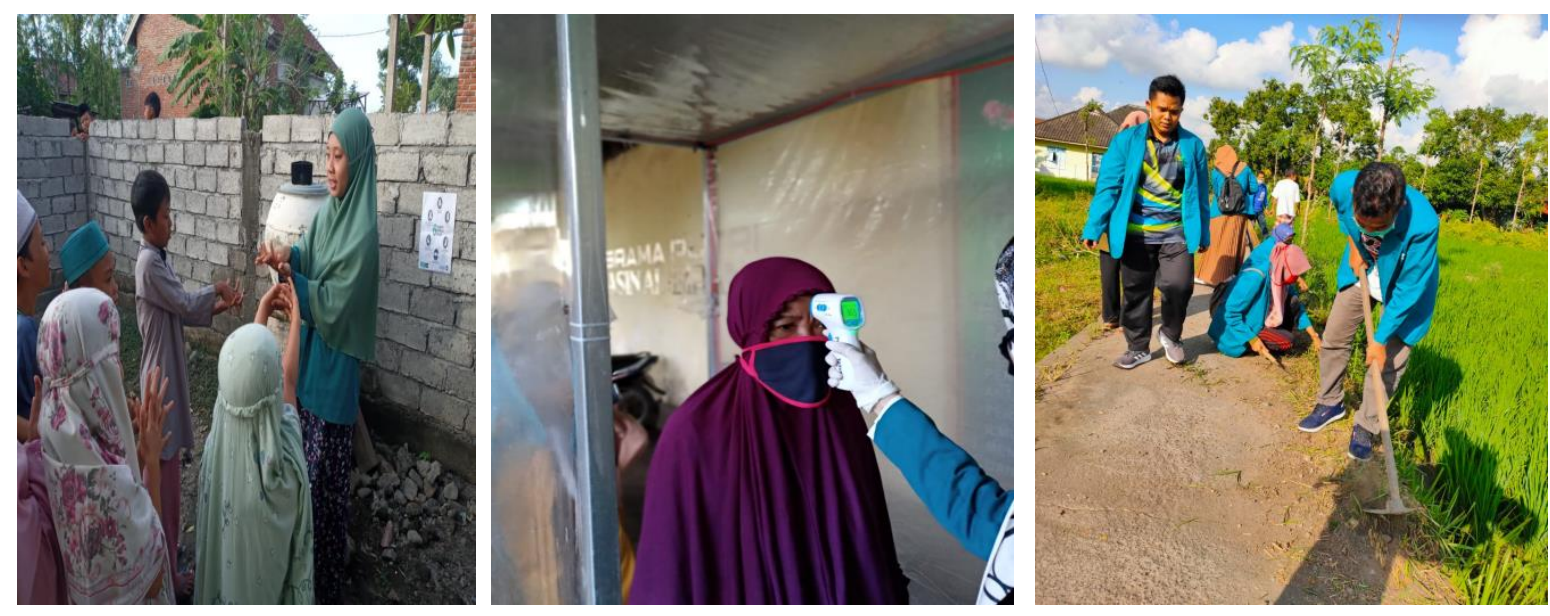

\section{Gambar 5}

Sosialisasi Hidup Bersih dan Sehat

\section{c. Pembagian masker}

Upaya mencegah dan melindungi masyarakat dari penyebaran Covid-19, mahasiswa KKP-DR UIN Mataram membagikan masker kepada masyarakat Desa Dasan Tapen. Masker dibagikan agar masyarakat menggunakannya pada saat beraktivitas di luar rumah. Dengan adanya pembagian masker ini, diharapkan dapat menumbuhkan kesadaran masyarakat akan pentingnya penggunaan masker sebagai salah satu pelindung diri dan secara tidak langsung mendukung pemerintah untuk menekan angka penyebaran Covid-19. Masker yang dibagikan juga terbuat dari kain nonmedis yang dapat dicuci dan digunakan secara berulang. Pembagian masker kain kepada masyarakat Desa Dasan Tapen bertujuan juga untuk 
mengedukasi masyarakat dengan harapan masyarakat bisa membuat sendiri masker berbahan dasar kain tersebut. Gambar 6 berikut menjelaskan bahwa mahasiswa KKP-DR UIN Mataram membagikan masker kepada warga masyarakat.
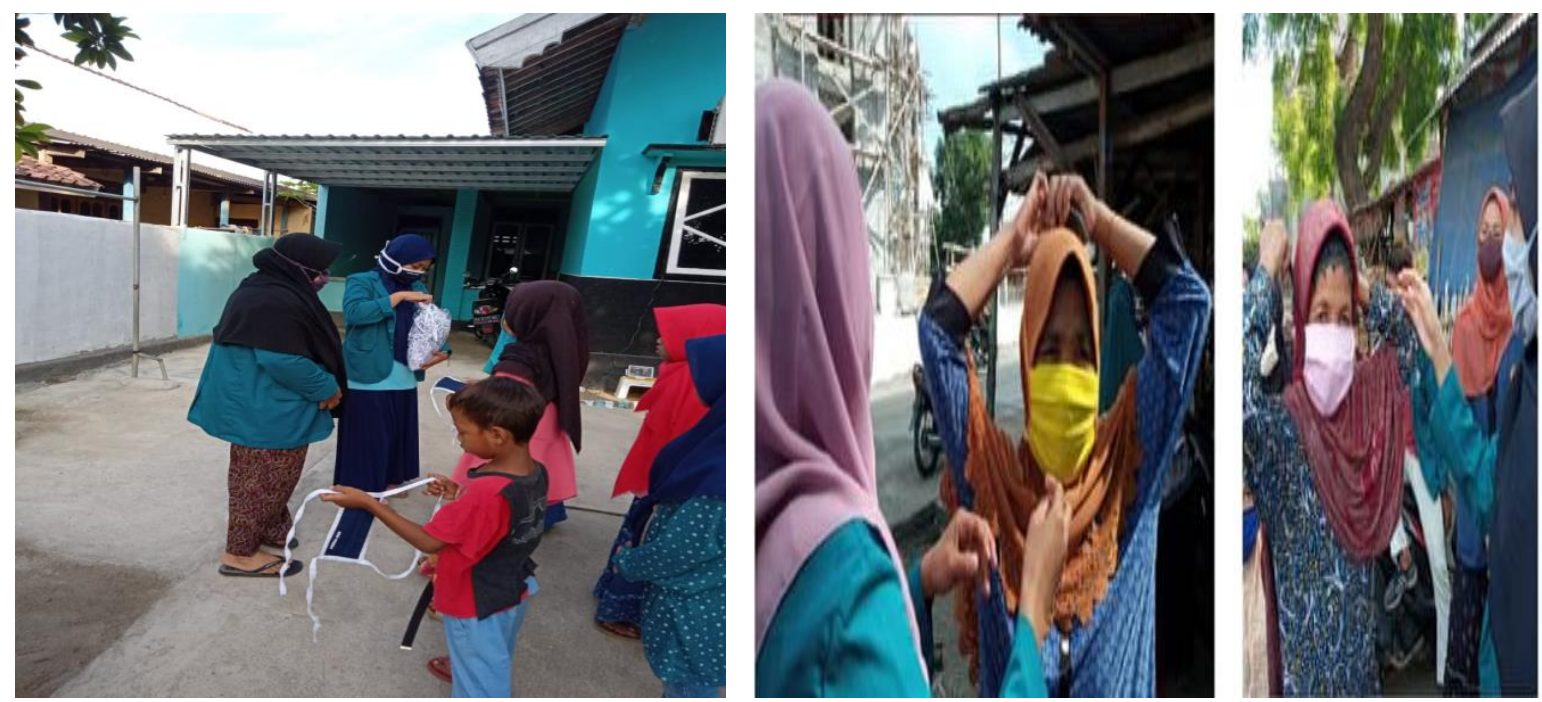

\section{Gambar 6}

Pembagian Masker

\section{d. Pembuatan dan pembagian hand sanitize}

Agar dapat mengoptimalkan langkah pencegahan dan menangkal Covid-19, mahasiswa KKP-DR UIN Mataram juga memfasilitasi warga membuat hand sanitizer. Pembuatan hand sanitizer ini diracik sendiri dengan menggunakan bahan-bahan yang tersedia di sekitar warga, seperti daun sirih. Setelah dibuat, mahasiswa KKP-DR UIN Mataram juga membagikannya kepada warga. Gambar 7 di bawah ini menjelaskan bahwa mahasiswa KKPDR UIN Mataram membuat dan membagikan hand sanitizer.

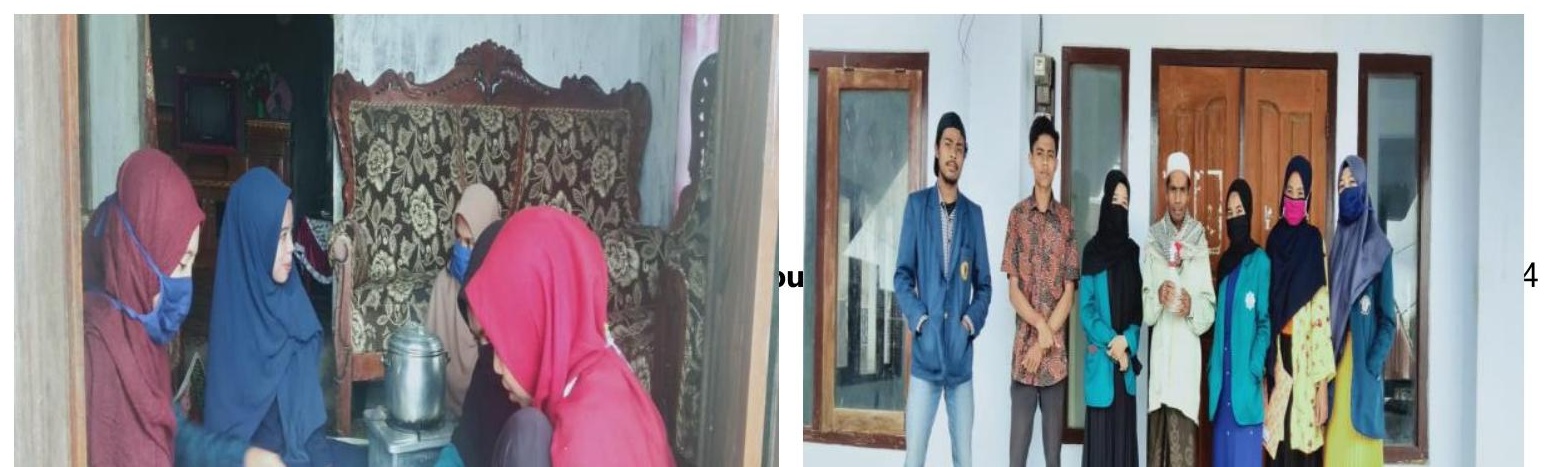




\section{Gambar 7}

Pembuatan dan Pembagian Hand Sanitizer

\section{e. Penyemprotan disinfektan}

Mahasiswa KKP-DR UIN Mataram juga melakukan penyemprotan disinfektan di tempattempat umum untuk mencegah penyebaran Covid-19. Penyemprotan disinfektan adalah cara menghilangkan atau membunuh segala hal yang terkait mikroorganisme baik virus maupun bakteri pada objek permukaan benda mati. Penyemprotan disinfektan ini dilakukan ke tempat-tempat umum seperti masjid, tempat perbelanjaan, dan lain sebagainya. Dengan dilakukan penyemprotan disinfektan ini, diharapakan dapat memutus rantai penyebaran Covid-19 yang ada di Desa Dasan Tapen. Penyemprotan disinfektan ini dibantu juga oleh karang taruna yang ada di Desa Dasan Tapen. Gambar 8 di bawah ini terlihat mahasiswa KKP-DR UIN Mataram melakukan persiapan dan penyemprotan disinfektan pada salah satu tempat umum.
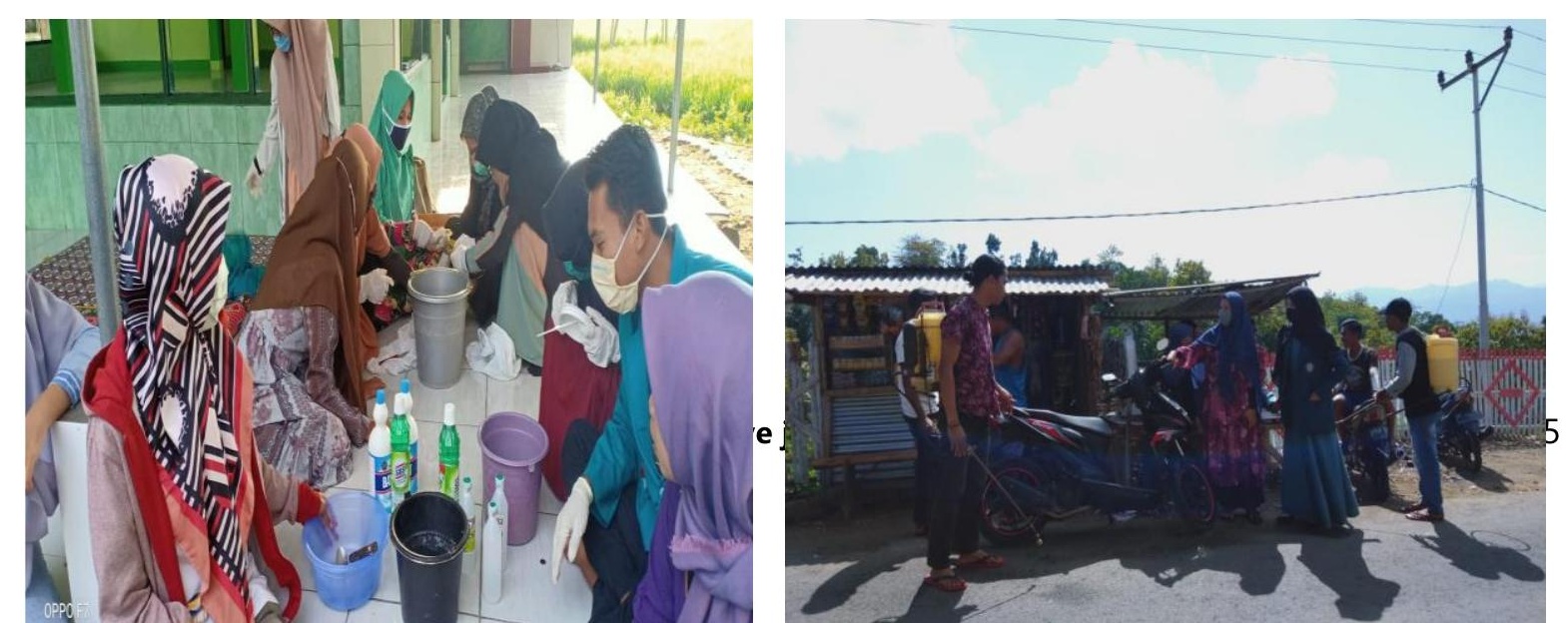


\section{Gambar 8}

Persiapan dan Penyemprotan Disinfektan

\section{Kesimpulan}

UIN Mataram sebagai bagian dari lembaga pemerintah di bawah Lingkungan Kementerian Keagamaan Republik Indonesia ikut terlibat dan berperan aktif dalam membantu masyarakat dan pemerintah menanggulangi pandemi Covid-19. UIN Mataram juga dapat menjadi solution maker terhadap permasalahan yang sedang dihadapi pada masa pandemi tersebut.

Program KKP-DR atau Kuliah Kerja Partisipatif Dari Rumah merupakan salah satu strategi yang dilakukan oleh UIN Mataram. Melalui KKP-DR ini, UIN Mataram berupaya mensinergikan programnya dengan program pemerintah dalam membantu percepatan penanganan dan pencegahan Covid-19. UIN Mataram mengerahkan keterlibatan mahasiswa yang langsung dapat bersentuhan dengan masyarakat melalui program KKP-DR ini. Berbagai program, strategi, dan kebijakan pun diambil untuk menyiasati keterlibatannya.

Salah satu lokasi KKP-DR, yakni di Desa Dasan Tapen Kecamatan Gerung Kabupaten Lombok Barat. Pelaksanaan KKP-DR dilakukan melalui berbagai program pilihan yang sesuai dengan keadan dan kebutuhan di lokasi KKP-DR dengan pemanfaatan IPTEK secara online. Programprogram pilihan yang dimaksudkan di sini adalah program pada bidang pendidikan dan bidang kesehatan. Pada program pendidikan, mahasiswa KKP-DR melakukan dampingan belajar dengan berkunjung ke rumah-rumah warga, membentuk kelompok belajar, dan kelompok mengaji alQur'an, sedangkan pada program kesehatan, mahasiswa KKP-DR melakukan edukasi masyarakat berupa kerja nyata pencegahan dan penyebaran Covid-19, seperti: penyebaran pamflet, sosialisasi hidup bersih dan sehat, pembagian masker, pembuatan dan pembagian hand sanitizer, serta penyemprotan disinfektan.

Dengan keterlibatan mahasiswa UIN Mataram dalam KKP-DR ini, diharapkan UIN Mataram telah berkontribusi dalam penanganan dan penyebaran Covid-19. Mahasiswa juga diharapkan untuk terus berbuat bagi masyarakat yang merupakan salah satu kewajiban dalam Tridharma perguruan tinggi. Masyarakat juga diharapkan untuk taat dan patuh kepada pemerintah sehingga dapat menekan angka penyebaran Covid-19.

\section{Ucapan Terima Kasih}


participative journal : Jurnal Pengabdian Pada Masyarakat

Penulis mengucapkan banyak terima kasih kepada LP2M UIN Mataram atas kesempatan diberikan kepada penulis dalam melakukan kegiatan Pengabdian Pada Masayarakat serta para mahasiswa KKP-DR.

\section{Footnote}

1) Tim P2M LP2M UIN Mataram, Buku Panduan Kuliah Kerja Partisipatif 2020: Penanggulangan Covid-19 Berbasis Moderasi Beragama (Mataram: P2M-LP2M UIN Mataram, 2020), h. 1.

2) Menteri Pendidikan dan Kebudayaan (Mendikbud), Surat Edaran (SE) Nomor 4 Tahun 2020 Tanggal 24 Maret 2020.

3) Firman Firman and Sari Rahayu, "Pembelajaran Online di Tengah Pandemi Covid-19," Indonesian Journal of Educational Science (IES) (2020).

4) Dian Ratu Ayu Uswatun Khasanah, Hascaryo Pramudibyanto, and Barokah Widuroyekti, "Pendidikan dalam Masa Pandemi Covid-19," Jurnal Sinestesia (2020).

5) Dyah Restuning Prihati, Maulidta Karunianingtyas Wirawati, and Endang Supriyanti, "Analisis Pengetahuan dan Perilaku Masyarakat di Kelurahan Baru Kotawaringin Barat tentang Covid 19," Malahayati Nursing Journal (2020).

6) Walsyukurniat Zendrato, "Gerakan Mencegah daripada Mengobati terhadap Pandemi Covid-19," Jurnal Education and Development (2020).

7) Yuliana, "Corona Virus Diseases (Covid -19); Sebuah Tinjauan Literatur," Wellness and healthy magazine (2020).

8) Biro Komunikasi dan Pelayanan Masyarakat, Kementerian Kesehatan RI, "Waspada Penularan COVID-19 di dalam Ruangan", dalam https://www.kemkes.go.id/article/view/20071300003/waspada-penularan-covid-19di-dalam-ruangan.html diambil tanggal 24 September 2020, Pukul 20.00 Wita

9) Tim Komunikasi Komite Penanganan Corona Virus Disease 2019 (COVID-19) dan Pemulihan Ekonomi Nasional, "Jumlah Kasus Aktif di Berbagai Daerah Cenderung Menurun" dalam https://covid19.go.id/p/berita/jumlahkasus-aktif-di-berbagai-daerah-cenderung-menurun diambil tanggal 24 September 2020, Pukul 20.00 Wita.

10) Kementerian Pendidikan dan Kebudayaan, Surat Edaran Nomor 15 Tahun 2020 tentang Pedoman Penyelenggaraan Belajar dari Rumah dalam Masa Darurat Penyebaran Corona Virus Disease (Covid-19), (Jakarta: Kemendikbud, 2020), h. 1-2

11) Zendrato, "Gerakan Mencegah daripada Mengobati terhadap Pandemi Covid-19."

12) Antara, Adinda Pryanka, and Sapto Andika Candra, "Empat Sektor Ekonomi yang Paling Tertekan Pandemi Covid-19," Republika.Co.Id, 2020.

13) Rahma Ainul Mardiya dan R. Nunung Nurwati, "Dampak Pandemi Covid-19 terhadap Peningkatan Angka Pengangguran di Indonesia," Kesejahteraan Sosial (2020).

14) Firman Firman and Sari Rahayu, "Pembelajaran Online di Tengah Pandemi Covid-19," Indonesian Journal of Educational Science (JES) (2020).

15) Dian Ratu Ayu Uswatun Khasanah, Hascaryo Pramudibyanto, and Barokah Widuroyekti, "Pendidikan dalam Masa Pandemi Covid-19," Jurnal Sinestesia (2020).

\section{Daftar Pustaka}

Antara, Adinda Pryanka, \& Sapto Andika Candra, "Empat Sektor Ekonomi yang Paling Tertekan Pandemi Covid-19," Republika.Co.Id, 2020. 
Biro Komunikasi dan Pelayanan Masyarakat, Kementerian Kesehatan RI, "Waspada Penularan COVID-19 di dalam Ruangan", dalam https://www.kemkes.go.id/article/view/ 20071300003/waspada-penularan-covid-19-di-dalam-ruangan.html diambil tanggal 24 September 2020, Pukul 20.00 Wita

Dian Ratu Ayu Uswatun Khasanah, Hascaryo Pramudibyanto, and Barokah Widuroyekti, "Pendidikan dalam Masa Pandemi Covid-19," Jurnal Sinestesia (2020).

Dyah Restuning Prihati, Maulidta Karunianingtyas Wirawati, and Endang Supriyanti, "Analisis Pengetahuan dan Perilaku Masyarakat di Kelurahan Baru Kotawaringin Barat tentang Covid 19," Malahayati Nursing Journal (2020).

Firman Firman \& Sari Rahayu, "Pembelajaran Online di Tengah Pandemi Covid-19," Indonesian Journal of Educational Science (IJES) (2020).

Kementerian Pendidikan dan Kebudayaa, Surat Edaran (SE) Nomor 4 Tahun 2020 Tanggal 24 Maret 2020.

Kementerian Pendidikan dan Kebudayaan. Surat Edaran Nomor 15 Tahun 2020 tentang Pedoman Penyelenggaraan Belajar dari Rumah dalam Masa Darurat Penyebaran Corona Virus Disease (Covid-19). Jakarta: Kemendikbud, 2020.

Rahma Ainul Mardiya \& R. Nunung Nurwati, "Dampak Pandemi Covid-19 terhadap Peningkatan Angka Pengangguran di Indonesia," Kesejahteraan Sosial (2020).

Tim Komunikasi Komite Penanganan Corona Virus Disease 2019 (COVID-19) dan Pemulihan Ekonomi Nasional, "Jumlah Kasus Aktif di Berbagai Daerah Cenderung Menurun" dalam https://covid19.go.id/p/berita/jumlah-kasus-aktif-di-berbagai-daerah-cenderung-menurun diambil tanggal 24 September 2020, Pukul 20.00 Wita.

Tim P2M LP2M UIN Mataram. Buku Panduan Kuliah Kerja Partisipatif 2020: Penanggulangan Covid-19 Berbasis Moderasi Beragama. Mataram: P2M-LP2M UIN Mataram, 2020.

Walsyukurniat Zendrato, "Gerakan Mencegah daripada Mengobati terhadap Pandemi Covid-19," Jurnal Education and Development (2020).

Yuliana, "Corona Virus Diseases (Covid -19); Sebuah Tinjauan Literatur," Wellness and healthy magazine (2020).

Zendrato, "Gerakan Mencegah daripada Mengobati terhadap Pandemi Covid-19." 